\title{
CHANGES IN THE DENTOFACIAL MORPHOLOGY BETWEEN CLASS II PATIENTS 4 TREATED WITH ONE OF THE TWO TREATMENT MODALITIES: FUNCTIONAL APPLIANCE AND HEADGEAR. A RETROSPECTIVE CEPHALOMETRIC STUDY \\ SINIF II HASTALARININ TEDAVİSİNDE KULLANILAN 2 TEDAVİ YÖNTEMİNDEN ACTİVATÖR VE HEADGEAR İLE OLUŞAN DENTOFASİYAL MORFOLOJİ DEĞİŞİMLERİ. BİR RETROSPEKTİF SEFALOMETRİK ÇALIŞMA
}

Prof. Dr. Nihat KILIÇ*

Prof. Dr. Abdulvahit ERDEM*

Dr. Sema TUNÇ**

Makale Kodu/Article code: 4888

Makale Gönderilme tarihi: 22.02.2021

Kabul Tarihi: 02.08.2021

DOI : $10.17567 /$ ataunidfd. 977613
Nihat Kılıc: $O R C I D$ ID: 0000-0002-1753-1380

Abdulvahit Erdem: ORCID ID: 0000-0002-6151-3470

Sema Tunç: ORCID ID: 0000-0001-6831-2957

\section{ABSTRACT}

Aim: To compare changes in dentofacial morphology between Angle class II patients treated with one of two treatment modalities: functional appliance and headgear.

Material and Methods: Activator group comprised 14 Class II patients (mean age, 13.54 years), headgear (HG) group 15 Class II patients (mean age, 11.56 years) and control group 14 Class I subjects (mean age, 11.57 years). Pre-treatment/baseline (T1) and post-treatment/observation (T2) lateral cephalograms were retrospectively analyzed using a standard cephalometric analysis. Data were analyzed by paired $t$ test, analysis of variance (ANOVA) and Tukey HSD tests.

Results: A point moved forward 0.50 and $0.51 \mathrm{~mm}$ in activator and control groups, but moved backward $0.37 \mathrm{~mm}$ in $\mathrm{HG}$ group, with no significant difference between groups. B point moved forward 3.32, 1.27 and $0.96 \mathrm{~mm}$ in activator, HG and control groups respectively, that significantly greater in activator group compared to other groups ( $p<.01$ ). U1-SN angle decreased (7.39 degree) and IMPA increased (5.14 degree) significantly activator group, whereas U1-SN angle and IMPA showed small and insignificant changes (less than one degree) in HG and control groups. No significant difference observed between the groups in regard to changes in upper lip position, nasolabial angle, mandibular plane angle and mandibular body length. Favorable soft tissue facial profile changes were observed in the groups, but the changes are prominent in activator group $(\mathrm{p}<.05)$

Conclusion: HG group showed small and insignificant dentofacial changes. Functional appliance group showed favorable skeletal but unfavorable dentoalveolar changes. However, this group experienced more prominent and positive effects on soft tissue facial profile.

Key words: Andresen activator. Headgear, Cephalometry

ÖZ

Amaç: Sınıf II hastalarının tedavisinde kullanılan 2 tedavi yönteminden activatör ve Headgear ile oluşan dentofasiyal morfoloji değişimlerini karşılaştırmaktır.

Materyal ve Yöntem: Aktivatör grubu Sınıf II malokluzyonlu 14 bireyden (ortalama yaşları $13.54 \pm 1.85$ yıl), Headgear (HG) grubu Sınıf II malokluzyonlu 15 bireyden (ortalama yaşları $11.56 \pm 0.97$ yll) ve kontrol grubu Sınıf I kapanış ilişkili14 bireyden (ortalama yaşları $11.56 \pm 1.21 \mathrm{yıl}$ ) oluşmaktadır. Tüm bireylerden tedavi/gözlem öncesi (T1) ve tedavi/gözlem periyodu sonrasında sefalometrik (T2) filmler alındı ve bu filmler standart sefalometrik analiz ile incelendi. Elde edilen veriler eşleştirilmiş $t$ testi, ANOVA ve Tukey HSD testleri ile analiz edildi.

Bulgular: A noktası aktivatör ve kontrol gruplarında sırasıyla 0.50 ve $0.51 \mathrm{~mm}$ öne doğru ve HG grubunda $0.37 \mathrm{~mm}$ geriye doğru hareket gösterdi, ancak bu hareketler gruplar arasında istatistiksel olarak önemsizdi. B noktası aktivatör, HG ve kontrol gruplarında sırasıyla 3.32, 1.27 and $0.96 \mathrm{~mm}$ öne doğru hareket gösterdi ve aktivatör grubundaki hareket miktarı diğer gruplardan istatistiksel olarak önemli miktarda fazla bulundu. Aktivatör grubunda U1-SN açıS önemli oranda $(p<.001)$ azalıp (7.39 derece) ve IMPA açısı ise önemli oranda $(p<.001)$ artarken (5.14 derece), bu açוlar diğer 2 grupta 1 dereceden az olacak şekilde önemsiz ve küçük değişimler gösterdi. Üst dudağın pozisyonu, nazolabial açı, mandibular düzlem açısı ve korpus uzunluğunda ise gruplar arasında istatistiksel olarak önemli farklı değişimler gözlemlenmedi. Yumuşak doku yüz profilinde olumlu değişimler tüm gruplarda görüldü, ancak bu değişimlerin activatör grubunda daha belirgindi $(p<.05)$.

Sonuçlar: HG grubu küçük ve önemsiz dentofasiyal değişimler gösterdi. Aktivatör grubu olumlu iskeletsel değişimler göstermiş olup, bu grupta istenmeyen dentoalveolar değişimler de meydana gelmiştir. Ancak, aktivatör grubunda yumuşak doku yüz profilinde daha belirgin ve olumlu (pozitif) değişimler gözlemlenmiştir.

Anahtar Kelimeler: Andresen aktivatörü, Headgear, Sefalometri.

${ }^{*}$ Department of Orthodontics.Faculty of Dentistry. Atatürk University. Erzurum. Turkey. ${ }^{* *}$ Private Practice. Istanbul. Turkey.

Kaynakça Bilgisi: Kılıç N, Erdem A, Tunç S. Sınıf II hastalarının tedavisinde kullanılan 2 tedavi yönteminden activatör ve headgear ile oluşan dentofasiyal morfoloji değişimleri. bir retrospektif sefalometrik çalışma . Atatürk Üniv Diş Hek Fak Derg 2021; 31: 500-6.

Citation Information: Kilinc $N$, Erdem $A$, Tunc $S$. Changes in the dentofacial morphology between class ii patients treated with one of the two treatment modalities: functional appliance and headgear. a retrospective cephalometric study. J Dent Fac Atatürk Uni 2021; 31: 500-6. 


\section{INTRODUCTION}

Skeletal and dental discrepancies of Class II malocclusions are generally treated with altering the maxillary and/or mandibular growth patterns of the patients. Headgear and activator are commonly used to obtain ideal jaw relationship and balanced faces in Class II patients. It has been known that extra oral appliances (Headgear-HG) exert a posterior force on the maxillary dentition and maxilla, while functional appliances exert a reciprocal force between the two jaws affecting not only the maxilla and maxillary dentition but also the entire lower jaw and mandibular dentition [1].

Several treatment modalities are viable for Class II correction. ${ }^{1-11}$ HG or functional treatment included activator, Bianator or Frankel appliance have been reported favorable outcomes for correction of Class II cases. ${ }^{1-3,8-10}$

Some authors ${ }^{1}$ claimed that patients treated with functional appliance (Bianator) or headgear experienced similar outcomes after the treatments, and he skeletal changes largely attributable to enhanced mandibular growth in both headgear and bionator subjects. According to these authors, both treatments corrected Angle class II molar relationships, reduced overjets and apical base discrepancies, and caused posterior maxillary tooth movement. However, the others ${ }^{2}$ claimed that headgear and Bianator appliances had different growth effects on the maxilla and mandible although the Class II correction was similar in both appliances. Tulloch et $\mathrm{al}^{2}$ and Haralabakis et $\mathrm{al}^{3}$ found that headgear had significant restriction effect on forward maxillary growth, while the functional appliance caused greater mandibular growth stimulation. This controversy remains unanswered. On the other hand, difference in orthopedic effect and dentofacial facial changes between HG with activator treatments, two standard treatment modalities for Angle Class II patients, remains unclarified. Therefore, the aim of this study was to compare changes in dentofacial morphology between Angle class II patients treated with one of two treatment modalities: functional appliance and headgear, and to distinguish superiorities of these treatment modalities each other.

\section{MATERIALS AND METHODS}

This retrospective study was carried out on two groups of subjects with Class II division 1 malocclusion and a group of subjects with Class I occlusion. First group was consisted of 14 patients with Class II division 1 malocclusion (mean age. 13.54 \pm 1.85 years), who underwent functional treatment with Andresen activator (Activator group). Second group was consisted of 15 patients with Class II division 1 malocclusion (mean age. $11.56 \pm 0.97$ years), who underwent combined headgear treatment (HG group). The third group was consisted of 14 subjects with Class I occlusion (mean age. $11.57 \pm$ 1.21 years) (Control groups). This study was approved by the Ethical Committee of the Atatürk University, Faculty of Dentistry (Number, 2017/06).

The Andresen activator was constructed that based on a registration bite taken with 6 to $8 \mathrm{~mm}$ of mandibular protrusion and $3 \mathrm{~mm}$ of vertical opening. The appliance included a labial bow prepared with 0.8 $\mathrm{mm}$ round stainless steel wire in front of the maxillary anterior teeth, and it included 2-3 mm acyclic capping over to lower anterior teeth. Reactivation of the appliance was done by construction of a new appliance, when necessary.

A combined headgear in included short outer bow and an inner bow with stops ended mesial ends of the molar tubes. Headgears were adjusted at each appointment to deliver 16 ounces of force per side. Subjects were instructed to wear the Andresen activator or HG at least 14-16 hours in a day.

Cephalometric films were chosen from the achieve files in Orthodontic Department of Dentistry Faculty, Atatürk University, for the three groups mentioned above. All of the cephalometric films were taken using the same cephalostat (Siemens Nanodor 2.Siemens AG. Wittelsbacherplatz 2, 80333, Munich, Germany) in a habitual, unstrained body posture. The subjects were told to keep their teeth in centric occlusion during the exposure, and special attention was given to the lips be at rest to overcome possible soft tissue distortion.

Cephalometric head films were obtained from all of the subjects before treatment/observation (T1) and after treatment/observation period (T2).

Treatment period was $8.53 \pm 3.51$ months in activator group, while $6.87 \pm 2.82$ months in $\mathrm{HG}$ group. Observation period was $7.50 \pm 0.48$ months in the control group. 
Eight linear and 5 angular parameters were measured on the radiographs to determine the treatment and growth changes. These measurements were adopted from the previous studies of Varlik et $\mathrm{al}^{12}$ and Nanda et $\mathrm{al}^{13}$ (Figure 1 and 2).

The data were analyzed by means of paired $t$ test for intra-group comparisons and by means of analysis of variance (ANOVA) and Tukey HSD tests for inter-group comparisons.

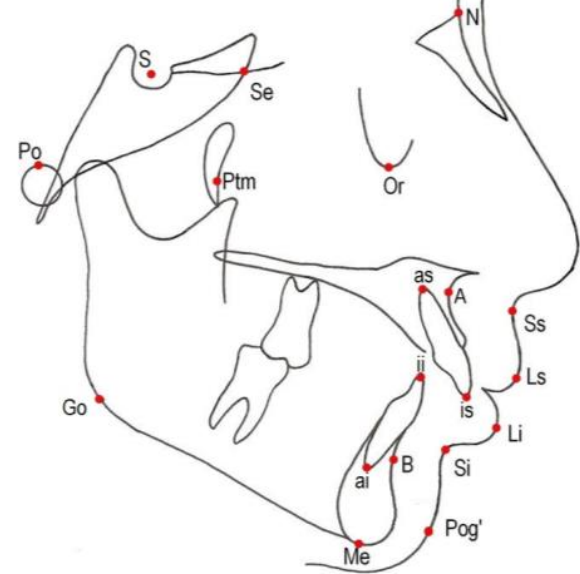

Figure 1.Landmarks used in the study.

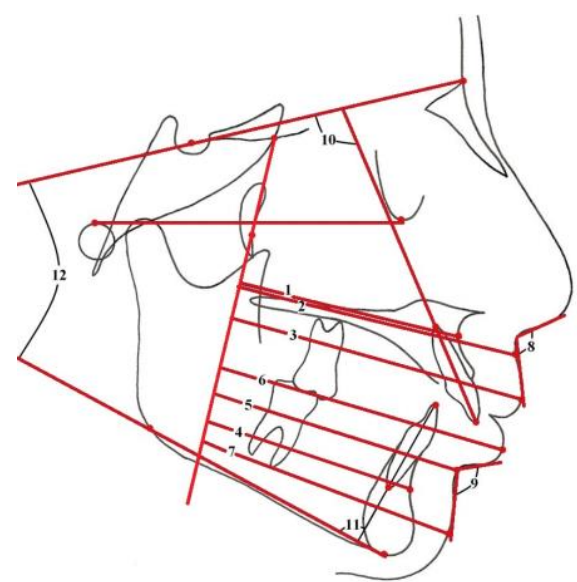

Figure 2.Linear and angular measurements used in the present study:

(1) A-y. (2) Ss-y. (3) Ls-y.(4) B-y.(5) Si-y.(6) Li-y.(7) Pog'y.(8) Nasolabialangle. (9) Labiomental angle. (10) U1SN.(11) IMPA. (12) SN-GoMe.

\section{RESULTS}

Mean age of the subjects in the activator group is significantly greater than those in $\mathrm{HG}$ and control groups, with no significant difference between the HG and control groups. No significant difference was observed between the all groups in regard to mean treatment/observation periods.
Means and standard deviations of the parameter in all groups at baseline (T1) are shown in Table 1 . The means of the measurements at T1 and $\mathrm{T} 2$ in each groups and their within group comparisons are shown in Table 2.

Table 1. Means and standard deviations of the parameter in all groups at pretreatment/baseline (TO)

\begin{tabular}{|c|c|c|c|c|c|c|}
\hline & \multicolumn{2}{|c|}{ Activator Group (I) } & \multicolumn{2}{|c|}{$\begin{array}{c}\text { Headgear group } \\
\text { (II) }\end{array}$} & \multicolumn{2}{c|}{ Control Group (III) } \\
\hline Parameters & Mean & $\begin{array}{c}\text { Std. } \\
\text { Deviation }\end{array}$ & Mean & $\begin{array}{c}\text { Std. } \\
\text { Deviation }\end{array}$ & Mean & $\begin{array}{c}\text { Std. } \\
\text { Deviation }\end{array}$ \\
\hline A-y & 56.39 & 3.19 & 55.93 & 3.28 & 51.11 & 3.01 \\
\hline Ss-y & 72.07 & 3.52 & 70.80 & 4.75 & 66.25 & 3.61 \\
\hline Ls-y & 77.71 & 3.56 & 75.80 & 5.22 & 70.86 & 4.76 \\
\hline B-y & 51.96 & 6.07 & 54.60 & 7.36 & 53.86 & 5.83 \\
\hline Si-y & 62.43 & 6.56 & 65.13 & 6.54 & 65.11 & 5.48 \\
\hline Li-y & 73.18 & 5.76 & 73.60 & 6.38 & 71.25 & 5.35 \\
\hline Pog'-y & 67.25 & 6.06 & 67.37 & 7.43 & 69.71 & 6.85 \\
\hline $\begin{array}{c}\text { Nasolabial } \\
\text { angle }\end{array}$ & 105.96 & 16.97 & 122.00 & 15.33 & 112.39 & 14.65 \\
\hline $\begin{array}{c}\text { Labiomental } \\
\text { angle }\end{array}$ & 90.50 & 16.01 & 107.17 & 24.81 & 122.68 & 16.85 \\
\hline U1-SN & 105.07 & 7.62 & 108.27 & 7.14 & 100.14 & 7.78 \\
\hline \begin{tabular}{c} 
IMPA \\
\hline SN-GoMe
\end{tabular} & 38.68 & 6.24 & 101.47 & 4.99 & 93.14 & 6.30 \\
\hline GoMe & 70.54 & 4.10 & 69.60 & 3.23 & 70.18 & 2.81 \\
\hline
\end{tabular}

Ss-y, B-y, Si-y, Li-y, Pog'-y, labiomental angle, IMPA, and GoMe increased and U1-SN decreased significantly in the activator group. B-y and GoMe significantly increased in the HG group. A-y, Ss-y, Lsy, B-y, Si-y, Li-y, Pog'-y and GoMe increased significantly in the control group.

Inter-group comparisons of mean changes of the measurements made by ANOVA and TUKEY HSD test, and results of the statistical analysis are shown in Table 3. A point moved forward 0.5 and $0.51 \mathrm{~mm}$ in the activator group and control groups, but moved back $0.37 \mathrm{~mm}$ in HG group, with no significant difference between the groups. B point moved forward 3.32, 1.27 and $0.96 \mathrm{~mm}$ in the activator, HG and control groups respectively, that significantly greater in activator group compared to $\mathrm{HG}$ and control groups $(p<.01)$. U1-SN angle decreased 7.39, 0.63 and 0.60 degrees in the activator, $\mathrm{HG}$ and control groups respectively, that significantly greater in activator group compared to HG and control groups ( $p<.001)$. IMPA increased 5.14 and 0.22 degrees in the activator and control groups (respectively), but decreased 0.90 degree HG group, that significantly different in activator group compared to HG and control groups 
$(p<.001)$. No significant difference observed between the groups in regard to changes in upper lip position, nasolabial angle, mandibular plane angle and mandibular body length. Favorable soft tissue facial profile changes were observed in the groups, but the changes were prominent in activator group $(p<.05)$ (Table 3).

Table 2. The means of the measurements at T1 and T2 in each groups and their within group comparisons.

\begin{tabular}{|l|l|l|l|l|l|l|l|l|l|}
\hline & \multicolumn{2}{|c|}{$\begin{array}{c}\text { Activator } \\
\text { Group }\end{array}$} & \multicolumn{2}{|l|}{ Headgear group } & \multicolumn{3}{|l|}{ Control Group } & \\
\hline Parameters & $\mathrm{T} 1$ & $\mathrm{~T} 2$ & Sig. & $\mathrm{T} 1$ & $\mathrm{~T} 2$ & Sig. & $\mathrm{T} 1$ & $\mathrm{~T} 2$ & Sig. \\
\hline A-y & 56.39 & 56.89 & .265 & 55.93 & 55.57 & .330 & 51.11 & 51.62 & $\mathbf{. 0 1 8}$ \\
\hline Ss-y & 72.07 & 72.93 & $\mathbf{. 0 4 5}$ & 70.80 & 71.27 & .228 & 66.25 & 67.41 & $\mathbf{. 0 0 0}$ \\
\hline Ls-y & 77.71 & 77.39 & .586 & 75.80 & 75.93 & .750 & 70.86 & 72.15 & $\mathbf{. 0 0 1}$ \\
\hline B-y & 51.96 & 55.29 & $\mathbf{. 0 0 0}$ & 54.60 & 55.87 & $\mathbf{. 0 3 0}$ & 53.86 & 54.84 & $\mathbf{. 0 0 4}$ \\
\hline Si-y & 62.43 & 67.04 & $\mathbf{. 0 0 0}$ & 65.13 & 66.03 & .105 & 65.11 & 66.27 & $\mathbf{. 0 0 4}$ \\
\hline Li-y & 73.18 & 76.00 & $\mathbf{. 0 0 3}$ & 73.60 & 74.30 & .073 & 71.25 & 72.54 & $\mathbf{. 0 0 6}$ \\
\hline Pog'-y & 67.25 & 71.04 & $\mathbf{. 0 0 0}$ & 67.37 & 68.43 & .129 & 69.71 & 71.19 & $\mathbf{. 0 0 2}$ \\
\hline Nasolabial angle & 105.96 & 105.92 & .992 & 122.00 & 119.40 & .293 & 112.39 & 111.79 & .843 \\
\hline $\begin{array}{l}\text { Labiomental } \\
\text { angle }\end{array}$ & 90.50 & 116.64 & $\mathbf{. 0 0 1}$ & 107.17 & 112.13 & .192 & 122.68 & 121.23 & .501 \\
\hline U1-SN & 105.07 & 97.68 & $\mathbf{. 0 0 0}$ & 108.27 & 107.63 & .218 & 100.14 & 99.54 & .160 \\
\hline \multicolumn{1}{|c|}{ IMPA } & 98.68 & 103.82 & $\mathbf{. 0 0 0}$ & 101.47 & 100.57 & .098 & 93.14 & 93.37 & .444 \\
\hline SN-GoMe & 37.18 & 37.57 & .415 & 33.10 & 33.43 & .667 & 33.29 & 33.48 & .376 \\
\hline \multicolumn{1}{|c|}{ GoMe } & 70.54 & 72.46 & $\mathbf{. 0 0 0}$ & 69.60 & 70.83 & $\mathbf{. 0 0 0}$ & 70.18 & 71.36 & $\mathbf{. 0 0 1}$ \\
\hline
\end{tabular}

\section{Bold font indicates statistical significance}

Table 3. Inter-group comparisons of mean changes of the measurements (TUKEY HSD test).

\begin{tabular}{|c|c|c|c|c|c|c|c|c|c|}
\hline & \multicolumn{2}{|c|}{ Activator Group (I) } & \multicolumn{2}{|c|}{ Headgear group (II) } & \multicolumn{2}{c|}{ Control Group (III) } & \multicolumn{3}{|c|}{$\begin{array}{c}\text { Comparisons } \\
\text { Comparisons }\end{array}$} \\
\hline Parameters & Mean & $\begin{array}{c}\text { Std. } \\
\text { Deviation }\end{array}$ & Mean & $\begin{array}{c}\text { Std. } \\
\text { Deviation }\end{array}$ & Mean & $\begin{array}{c}\text { Std. } \\
\text { Deviation }\end{array}$ & I-II & I-III & II-III \\
\hline A-y & 0.50 & 1.61 & -0.37 & 1.41 & 0.51 & 0.71 & .185 & 1.000 & .176 \\
\hline Ss-y & 0.86 & 1.45 & 0.47 & 1.43 & 1.16 & 0.76 & .864 & .800 & .310 \\
\hline Ls-y & -0.32 & 2.15 & 0.13 & 1.59 & 1.29 & 1.18 & .750 & $\mathbf{. 0 4 0}$ & .166 \\
\hline B-y & 3.32 & 1.95 & 1.27 & 2.03 & 0.98 & 1.06 & $\mathbf{. 0 0 8}$ & $\mathbf{. 0 0 3}$ & .899 \\
\hline Si-y & 4.61 & 3.40 & 0.90 & 2.01 & 1.16 & 1.25 & $\mathbf{0 . 0 0 0}$ & $\mathbf{0 . 0 0 1}$ & 0.953 \\
\hline Li-y & 2.82 & 2.91 & 0.70 & 1.40 & 1.29 & 1.48 & $\mathbf{. 0 2 1}$ & .129 & .714 \\
\hline Pog'-y & 3.79 & 2.33 & 1.07 & 2.56 & 1.47 & 1.45 & $\mathbf{. 0 0 5}$ & $\mathbf{. 0 2 0}$ & .871 \\
\hline Nasolabial angle & -0.04 & 16.08 & -2.60 & 9.22 & -0.60 & 11.19 & .845 & .992 & .902 \\
\hline Labiomental angle & 26.14 & 24.02 & 4.97 & 14.02 & -1.45 & 7.85 & $\mathbf{. 0 0 4}$ & $\mathbf{. 0 0 0}$ & .557 \\
\hline U1-SN & -7.39 & 4.69 & -0.63 & 1.90 & -0.60 & 1.51 & $\mathbf{. 0 0 0}$ & $\mathbf{. 0 0 0}$ & 1.000 \\
\hline IMPA & 5.14 & 3.37 & -0.90 & 1.97 & 0.22 & 1.06 & $\mathbf{. 0 0 0}$ & $\mathbf{. 0 0 0}$ & .403 \\
\hline SN-GoMe & 0.39 & 1.75 & 0.33 & 2.94 & 0.20 & 0.80 & $\mathbf{. 9 9 7}$ & $\mathbf{. 9 6 5}$ & $\mathbf{. 9 8 2}$ \\
\hline GoMe & 1.93 & 1.38 & 1.23 & 0.86 & 1.18 & 1.01 & $\mathbf{. 2 1 9}$ & $\mathbf{. 1 8 3}$ & $\mathbf{. 9 9 0}$ \\
\hline
\end{tabular}

Bold font indicates statistical significance

\section{DISCUSSION}

This study was aimed to compare skeletal, dental, and soft tissue changes induced by activator or headgear treatment and to detect the superiorities of these treatment modalities on each other. Study groups consisted of Class II subjects, whom underwent either activator or HG treatments. A control group was composed to eliminate possible growth changes from the changes induced by the two treatment modalities. Since ethical principles did not allow postponement of treatment in the Class II subjects for scientific purposes, the subjects with acceptable occlusion, skeletal and dental Class I relationship formed control group.

Within group comparisons showed insignificant anterior movement of the maxilla (A-y) and significant anterior projection of the mandible and surrounding soft tissue structures (B-y, Si-y, Li-y, Pog'-y, labiomental angle) and increased lower incisor inclination, decreased upper incisor inclination and increased mandibular plane angle in the activator group. Insignificant anterior movement of the maxilla (A-y) and significant anterior projection of the mandible (B-y) was observed in the HG group. Maxilla and mandible and surrounding soft tissue structures (A-y, Ss-y, Ls-y, B-y, Si-y, Li-y, Pog'-y) showed significant anterior growth and increased lower anterior facial heights (GoMe) in the control group.

Haralabakis et al ${ }^{3}$ observed insignificant anterior movement of the maxilla and significant anterior projection of the mandible in their activator group, but restricted maxillary growth and increased mandibular growth in their HG group. These authors found insignificant changes in the vertical measurements (GoGn-SN, FMA) in both groups. Tulloch et $\mathrm{al}^{2}$ found significant anterior growth in control group, restricted maxillary growth in the HG group and insignificant skeletal maxillary movement in the functional appliance group (Bianator). On the other hand, significant mandibular anterior growths in the HG and control groups and insignificant mandibular growth in the Bianator group was reported in the study of Tulloch et $\mathrm{al}^{2}$. Upper incisor showed significant retroclination and lower incisors showed significant proclination in the activator group, whereas these teeth showed insignificant changes in the control and HG groups. Several studies found significant retroclination of upper incisors and proclination of the lower incisors after activator treatment. ${ }^{12}$

Inter-group comparison findings showed that both headgear and activator treatment did not resulted in greater restricted maxillary growth compared to control groups. In other words, both 
treatment options caused insignificant effect on maxillary growth compared to control subjects. Our results were also showed that activator treatment caused more anterior mandibular projection and resulted in a greater forward movement of the mandible.

Tulloch et $\mathrm{al}^{2}$ found that headgear treatment caused restricted maxillary growth (SNA angle reduced 0.92 degree during treatment), but functional appliance therapy caused a greater increase in mandibular length. Haralabakis et $\mathrm{al}^{3}$ compared dental and skeletal effects between HG and activator treatment, and they found only difference between the two treatment modalities in anteroposterior dimension was the significantly reduced SNA angle in the headgear group. Our findings are in disagreement with the findings of these two studies in regard to maxillary effects of the activator or HG.

On the other hand, findings of the present study are in agreement with the findings of Keeling et $\mathrm{al}^{1}$, since they observed that the subjects treated by functional appliance (bianator) or HG showed more skeletally class II corrections with mandibular growth, pronounced in activator group. These authors also found insignificant maxillary skeletal changes between HG and bianator groups and also between the treatment and control groups.

There is no clear consensus upon the growth stimulatory effect of activators on mandible. Findings of the studies carried out by several authors included Keeling et al. ${ }^{1}$ Tulloch et $\mathrm{al}^{2}$, Haralabakis et $\mathrm{al}^{3}$, and Luder $^{4}$ showed that activator therapy resulted in enhanced mandibular growth. Conversely, other researchers believe that activator therapy does not affect anteroposterior mandibular dimensions. ${ }^{8-10,14}$ In a prospective clinical trial, Nelson et al $^{10}$ assessed possible changes in position and size of the mandible in children treated with either the Fränkel appliance or Harvold activator, and they found no evident fact to support the opinion that either appliance was capable of altering the size of the mandible. Results of study of Nelson et al ${ }^{10}$ also revealed class II correction was mainly accomplished by both dental movements and positional changes of the condyle, since the condyles were positioned downward and forward and lower incisors proclined significantly during Fränkel function regulator or Harvold activator treatments.

We found that Class II correction was achieved posterior movement of maxillary posterior teeth in cervical HG group, while a significant more anterior mandibular projection and anterior movement of mandibular dentition in activator group.

In regard to dental changes observed in the present study, our results are consistent with the literature studies. ${ }^{3}$ Haralabakis et al $^{3}$ found differences in the movements of maxillary and mandibular molars with regional superimpositions in the activator and HG groups. The superimpositions revealed that maxillary molars moved posteriorly and inferiorly in cervical HG group, while mandibular molars moved toward to occlusal plane more in the activator groups.

As for skeletal changes observed in the present study, our findings are consisted with some studies ${ }^{15-}$

17 In the present study, activator treatment altered anterior projection of the mandible greater than $\mathrm{HG}$ and control groups, and this finding may result from several factors such as condylar growth stimulation and anterior displacement of the condyles and glenoid fossa. Since, B point and soft tissue pogonion showed significantly greater anterior movement in the activator group than those in the HG and control groups, while insignificant anterior moments between the HG and control groups. On the other hand, mandibular length, measured with the distance between the Go and Me points, showed insignificant different increases between the three groups, although $0.7 \mathrm{~mm}$ greater increase observed in the activator group.

Le Cornu et $\mathrm{al}^{17}$ found insignificant different changes in mandibular length, measured with the distance between the Go and Gn points, between the subjects treated with Herbst appliance and the Class II controls treated with fixed orthodontic appliances and Class II elastics.

Martins et $\mathrm{al}^{15}$ reported that subjects treated with a functional appliance (Bianator) had significantly greater anterior mandibular displacement than the subjects treated with a removable headgear splint.

Study of LeCornu et $\mathrm{al}^{17}$ showed that Class II correction with a fixed functional appliance (Herbst appliance) was mainly achieved with anterior displacement of the condyles and glenoid fossae along with maxillary restraint when compared with the treated Class II controls, and this finding might result in more anterior mandibular projection. According to these authors, alteration of anteroposterior projection of the mandible during functional appliance treatment can be attributed to "(1) changes in mandibular growth, (2) changes in the direction of growth, or (3) condylar/fossa positional changes". 
According to Vargervik and Harvold ${ }^{16}$, correction of Class II relationship can be achieved with combination of several mechanisms due to design and study of the activator: 1) inhibition of forward growth of the maxilla, 2) inhibition of mesial migration of maxillary teeth, 3) inhibition of maxillary alveolar height increase and extrusion of mandibular molars, 4) increased growth of the mandible, 5) anterior relocation of the glenoid fossae, 6) mesial movement of mandibular teeth, and 7) a combination of the above mechanisms.

A systematic review evaluated 14 systematic reviews, and this study showed existence of some evidence of small maxillary growth restrain with headgear and elongation of mandibular length with fixed or removable functional appliances, but the clinical relevance of latter result is still questionable ${ }^{14}$.

In our study, no significant different change was observed between the groups in regard to vertical dimensions (mandibular plane angle). In accordance with our findings, Haralabakis et $\mathrm{al}^{3}$ found minimal changes in Frankford-mandibular plan (FMA) and GoGn-SN angles in activator and HG groups, with no significant difference change between the groups.

This study was not free of limitations. The sample size in three groups was limited with respect to the generalizability of the findings. A larger sample size could increase the generalizability of the findings. Second, study groups (HG or Activator) and control group did unmatched according to mean age of the subjects. On the other hand, our study compared the mean changes in the activator or $\mathrm{HG}$ and growth changes in the control subjects Longitudinal craniofacial growth atlas ${ }^{18}$ studies or other growth studies $^{19}$ showed that annual ${ }^{18}$ or biannual ${ }^{18,19}$ increments of the maxilla and mandible in sagittal direction is relatively similar between age of 10 and 14 years. Third, an observation period of 6-8 months was considered to evaluate short-term changes in outcomes in the study groups. However, a long-term period would have been beneficial to better evaluate whether the changes remained stable or not in the study groups

\section{CONCLUSION}

Class II correction was achieved posterior movement of maxillary posterior teeth in HG group, since this group showed small and insignificant dentofacial changes. Functional appliance group showed favorable skeletal but unfavorable dentoalveolar changes. However, this group experienced more prominent and positive effects on soft tissue facial profile.

\section{ABBREVIATIONS}

HG: Headgear; ANOVA: Analysis of variance.

\section{DECLARATIONS}

Ethical Approval and Consent to participate

This study was approved by the Ethical Committee of the Atatürk

University, Faculty of Dentistry (Number, 2017/06).

Consent for publication

Not applicable.

Availability of supporting data

The datasets used and/or analyzed during the current study are available from the corresponding author on reasonable request. Funding

No funding was received.

Acknowledgements

Not applicable.

\section{REFERENCES}

1. Keeling SD, Wheeler TT, King GJ, Garvan CW, Cohen DA, Cabassa S, McGorray SP, Taylor MG Anteroposterior skeletal and dental changes after early Class II treatment with bionators and headgear. Am J Orthod Dentofac Orthop 1998; 113: 40-50.

2. Tulloch JF, Phillips C, Koch G, Proffit WR The effect of early intervention on skeletal pattern in Class II malocclusion: a randomized clinical trial. Am J OrthodDentofacialOrthop 1997; 111:391-400.

3. Haralabakis NB, Halazonetis DJ, Sifakakis IB Activator versus cervical headgear: superimpositional cephalometric comparison. Am J Orthod Dentofacial Orthop 2003; 123: 296-305.

4. Maetevorakul S, Viteporn S. Factors Influencing Soft Tissue Profile Changes Following Orthodontic Treatment in Patients With Class II Division 1 Malocclusion. Prog Orthod 2016; 17:13.

5. Heino T, Kokko H, Vuollo V, Pirttiniemi P. Effect of cervical headgear on dental arch area, shape and interarch dimensions: A randomized study. 2020; J Orofac Orthop doi: 10.1007/s00056-020-002640.

6. Falcão ICMCF, Valarelli FP, Canuto LFG, Oliveira RC, de Oliveira RCG, Cançado RH, Freitas KMS (2021). Soft tissue profile changes in Angle class II patients treated with Twin Force or intermaxillary elastics-a comparison. J Orofac Orthop 82:71-81.

7. Kochar GD, Londhe SM, Shivpuri A, Chopra SS, Mitra R, Verma M. Management of skeletal class II malocclusion using bimaxillary skeletal anchorage 
supported fixed functional appliances : A novel technique. J Orofac Orthop 2021; 82:42-53.

8. Hourfar J, Kinzinger GSM, Euchner L, Lisson JA. Differential skeletal and dental effects after orthodontic treatment with bite jumping appliance or activator: a retrospective cephalometric study. Clin Oral Investig 2020; 24:2513-21.

9. Looi LK, Mills JR. The effect of two contrasting forms of orthodontic treatment on the facial profile. Am J Orthod 1986; 89:507-17.

10. Nelson C, Harkness M, Herbison P. Mandibular changes during functional appliance treatment. Am J Orthod Dentofacial Orthop 1993; 104:153-61.

11. AL-Nimri K, Abo-Zomor M, Alomari S. Changes in mandibular position in treated Class II division 2 malocclusions in growing and non-growing subjects. Aust Orthod J 2016; 32:73-81.

12. Varlik S K, Gültan A, Tümer N. Comparison of the effects of Twin Block and activator treatment on the soft tissue profile. Eur] Orthod 2008; 30:12834.

13. Nanda RS, Meng H, Kapila S, Goorhuis J. Growth changes in the soft tissue facial profile. Angle Orthod 1990; 60:177-90.

14. D'Antò V, Bucci $R$, Franchi $L$, Rongo $R$, Michelotti A, Martina R Class II functional orthopaedic treatment: a systematic review of systematic reviews. J Oral Rehabil 2015; 42:624-42

15. Martins RP, da Rosa Martins JC, Martins LP, Buschang PH. Skeletal and dental components of Class II correction with the bionator and removable headgear splint appliances. Am J Orthod Dentofacial Orthop 2008; 134:732-741.

16. Vargervik K, Harvold EP. Response to activator treatment in Class II malocclusions. Am J Orthod 1985; 88:242-51.

17. LeCornu M, Cevidanes LH, Zhu H, Wu CD, Larson $B$, Nguyen T. Three-dimensional treatment outcomes in Class II patients treated with the Herbst appliance: a pilot study. Am J Orthod Dentofacial Orthop 2013; 144:818-30.

18. Riola ML, Moyers RE, McNamara JA, Hunter WS. An atlas of craniofacial growth and development. Ann Arbor, MI. Mosby 1974.

19. Ochoa BK, Nanda RS Comparison of maxillary and mandibular growth. Am J Orthod Dentofacial Orthop 2004; 125:148-59.

\section{Sorumlu Yazarın Yazışma Adresi}

Dr. Nihat KILIÇ

Atatürk Üniversitesi Diş Hekimliği Fakültesi

Ortodonti Anabilim Dalı

25240 Erzurum, TURKEY.

TIf: 90.442.2311807

Fax:+90.442.2312270-2360945

E mail: drnkilic@yahoo.com 